\title{
META ANALYSIS: THE EFFECTIVENESS OF FISH OIL ON PAIN RELIEF IN DYSMENORRHEA
}

\author{
Isnaini Novitasari'1), Eti Poncorini Pamungkasari²), Hanung Prasetya3) \\ ${ }^{1)}$ Masters Program in Public Health, Universitas Sebelas Maret \\ 2)Faculty of Medicine, Universitas Sebelas Maret \\ ${ }^{3)}$ Health Polytechnics, Ministry of Health Surakarta
}

\begin{abstract}
Background: The use of nonsteroidal anti-inflammatory drugs medications is a wellestablished effective therapy for both acute and chronic pain. However, highly studies reported their poor side effects and complications. An alternative treatment with fewer side effects that also reduces the inflammatory response and pain is believed to be omega-3 fatty acids. It is commonly found in fish oil and has have been widely used to treat pain associated with inflammatory conditions.

Subjects and Method: This was a systematic review and meta-analysis. The articles were collected from PubMed, Science Direct, ProQuest, Springer Link, Google Scholar databases. The inclusion criteria were full text, using English language, Randomized Control Trial (RCT) study, and dysmenorrhea pain level was measured by visual analog scale. Population $=$ women of reproductive age. Intervention $=$ fish oil. Comparison= placebo. Outcome $=$ dysmenorrhea. Quantitative synthesis used effect size (Standardized Mean Difference) run on RevMan 5.3 software with Random Effect Model.

Results: 6 studies were reviewed for meta analysis. This study had high heterogeneity between groups $\left(\mathrm{I}^{2}=92 \%\right.$; $<$ 0.0001). Fish oil consumption reduced dysmenorrhea than placebo (Standardized Mean Difference $=-1.01 ; 95 \% \mathrm{CI}=-1.6$ to $-0.42 ; \mathrm{p}=0.0007$ ).

Conclusion: Fish oil consumption reduces dysmenorrheal in women of reproductive age.
\end{abstract}

Keywords: fish oil, dysmenorrhea, inflammatory response, pain

\section{Correspondence:}

Isnaini Novitasari. Masters Program in Public Health, Universitas Sebelas Maret. Jl. Ir. Sutami 36A, Surakarta 57126, Central Java. Email: isnaininovitasari.711@gmail.com. Mobile: 085921790588. 